Strange, R. E. \& Dark, F. A. (1957). J. gen. Microbiol. 17, 525-537

\title{
Cell-Wall Lytic Enzymes at Sporulation and Spore Germination in Bacillus Species
}

\author{
By R. E. STRANGE AND F. A. DARK \\ Microbiological Research Establishment, Porton, Wiltshire
}

\begin{abstract}
SUMMARY: When washed sporulating cells of Bacillus cereus were incubated in buffer at $37^{\circ}$ in the presence of toluene, a partial autolysis occurred resulting in the freeing of mature and immature spores. The autolysate contained lytic enzymes which attacked vegetative cells and cell-wall preparations, releasing hexosaminecontaining peptides of characteristic constitution. The most active enzyme preparations were obtained from sporulating cells incubated for 1-2 hr. in buffer at $\mathbf{p H ~ 5 \cdot 0 -}$ 6.0. Two water-soluble lytic systems, enzyme $V$ and enzyme $S$ with $\mathrm{pH}$ optima near 4.5 and 8.0 respectively, were separated from the autolysate. Enzyme $S$ is probably identical with the lytic system present in spores of $B$. cereus and other Bacillus species and further observations on this system are described. When non-sporulating cells of $B$. cereus were incubated under similar conditions no obvious lysis or sporulation occurred and no cell-wall lytic activity could be demonstrated. In growing cultures of Bacillus cereus, considerable amounts of hexosamine-containing peptides were released into the medium during the period between the appearance of intracellular spores and free spores. It is suggested that enzyme $V$ may be mainly concerned with the release of free spores from sporangia and enzyme $S$ with the lytic processes which accompany spore germination.
\end{abstract}

Spore release from sporulating cells is a process which can be observed under the microscope and it occurs by dissolution of the vegetative cell. The process might be due to the independent or combined activity of lytic systems present in the cell and the culture medium. Intracellular and extracellular lytic systems derived from Bacillus species have been reported by Greenberg $\&$ Halvorson (1955), Nomura \& Hosoda (1956) and Norris (1957). The significance of the development of these lytic enzymes in growing cultures is not evident from the reports, although the suggestion is made that the autolytic substance described by Greenberg \& Halvorson might be responsible for vegetative cell lysis at sporulation (Nomura \& Hosoda, 1956). Powell \& Strange (1956) found that an intracellular cell-wall lytic system developed during sporulation of Bacillus cereus and, in a further investigation (Strange \& Dark, 1957), the partial purification and some properties of a lytic enzyme present in extracts of disintegrated resting-spores were described. It was considered that this enzyme released peptide from the spore coat during spore germination but it was not clear whether it or another enzyme dissolved the vegetative cell wall at sporulation.

In this report evidence is presented that sporulating cells of Bacillus cereus contain two cell-wall lytic enzymes, 'enzyme $V$ ' and 'enzyme S'. A partial separation of these enzymes is described and their properties compared. Further results are given which support the view that spore peptide (Strange \& 
Powell, 1954) is associated with the coat of the resting spore (Strange $\&$ Dark, $1956)$ and that it is released during germination or disintegration by enzymic activity of enzyme $\mathbf{S}$.

\section{METHODS}

\section{Preparation of cell-free solutions of lytic enzymes from sporulating cells and spores of Bacillus cereus}

Cultures of a laboratory strain of Bacillus cereus were grown at $37^{\circ}$ in 11 . flasks, each containing $200 \mathrm{ml}$. of potato extract medium (Robinow, 1951) enriched with $\frac{1}{10}$ th vol. of casein hydrolysate and yeast extract (Gladstone \& Fildes, 1940), on a rotary shaker as previously described (Powell \& Strange, 1956). Incubation was continued until intracellular spore formation was at an advanced stage and spore release had begun. The time of incubation varied from 17 to $19 \mathrm{hr}$. depending on the appearance of the cells in heat-fixed films stained with carbol fuchsin-nigrosin-methylene blue (Powell, 1950) which were examined at intervals. The sporulating cells were harvested by centrifugation at $0^{\circ}$ and washed twice with $0.9 \%(\mathrm{w} / \mathrm{v})$ saline and once with distilled water. Washed cells $(c .0 \cdot 9-1 \cdot 0 \mathrm{~g}$. dry weight from $1 \mathrm{l}$. medium) were suspended in distilled water $(20 \mathrm{ml}$.$) . A measured volume of suspension was mixed with$ an equal volume of McIlvaine's buffer and after the addition of toluene $\left(0.025 \mathrm{ml} . / \mathrm{ml}\right.$. suspension) the mixture was incubated at $37^{\circ}$. The effect of $\mathrm{pH}$ value and time of incubation on the recovery of enzymic activity from autolysates is described in Results. After incubation, the suspension was centrifuged at $6000 \mathrm{~g}$ for $20 \mathrm{~min}$. and the supernatant fluid filtered through sintered glass (porosity 5/3). The filtrate contained cell-wall lytic enzymes and was stored at $-10^{\circ}$.

Partially purified cell-wall lytic enzyme was prepared from disintegrated resting spores of Bacillus cereus as described by Strange \& Dark (1957).

Determination of enzymic activity. To determine the cell-wall lytic activity of enzyme preparations, a substrate of cell walls from non-sporulating cells of Bacillus cereus was used. The method for the preparation of cell walls was described in a previous paper and spontaneous lysis was prevented by heating for $15 \mathrm{~min}$. at $100^{\circ}$ (Strange \& Dark, 1957). Buffer systems in the $\mathrm{pH}$ range 3.0-9.6 were: McIlvaine's (0.1 M-citric acid +0.2 $\left.\mathrm{M}-\mathrm{Na}_{2} \mathrm{HPO}_{4}\right)$, pH 3.0-8.0; 0.1 M-tris-(hydroxymethyl)aminomethane/HCl (Gomori, 1946), pH 8.0-9.0; $0 \cdot 5 \mathrm{M}^{-\mathrm{Na}_{2}} \mathrm{CO}_{3} / \mathrm{NaHCO}_{3}, \mathrm{pH} \mathrm{9 \cdot 6}$. The effect of the lytic enzymes on the substrate was determined by estimation of the soluble combined amino-sugars released (Strange \& Dark, 1957) or by turbidity measurements in a Coleman Junior spectrophotometer at $450 \mathrm{~m} \mu$. For turbidity measurements a suspension (2.5 ml.) containing buffer $(1 \mathrm{ml}$.) enzyme solution, cobalt sulphate, $\left(50 \mu \mathrm{g} . \mathrm{Co}^{++}\right)$and sufficient substrate to give a $-\log T$ reading of $c .0 \cdot 35$ (c. $1.5 \mathrm{mg}$.) was prepared in an optical cuvette $(12 \times 75 \mathrm{~mm}$.). A control solution containing enzyme but no substrate was prepared to determine turbidity changes caused by precipitation which occurred mostly at acid $\mathrm{pH}$ values and usually increased during incubation. A second control tube contained substrate without enzyme. The optical densities of the three tubes 
were measured and they were incubated at $56^{\circ}$. Readings were taken at intervals after the tubes had been rapidly cooled to $15^{\circ}$ and lysis was expressed as percentage decrease of turbidity, allowance being made for changes due to precipitation of the enzyme preparation. The maximum decrease in turbidity varied from $\mathbf{5 5}$ to $\mathbf{7 5} \%$ according to the particular preparation of cell walls. When a number of enzyme solutions were compared they were tested under identical conditions and their activities expressed in terms of the time (min.) taken to produce $50 \%$ of the maximum possible lysis.

Analytical methods. These were as described in a previous paper (Strange \& Dark, 1957), but the method for the determination of $\alpha \epsilon$-diaminopimelic acid (DAP) was modified. An acid-hydrolysed sample containing 10-60 $\mu \mathrm{g}$. DAP was chromatographed on Whatman no. 1 paper using the technique of Rhuland, Work, Denham \& Hoare (1955). After reaction with ninhydrin in acetone, the olive-green spot corresponding in position to that of a standard of DAP was cut out and dropped into a test tube. Distilled water $(1 \mathrm{ml}$.), glacial acetic acid (1 ml.) and acid ninhydrin solution (1 ml.; Chinard, 1952) were added and the tube heated at $100^{\circ}$ for 5 min. (Work, 1957). After cooling, glacial acetic acid $(3 \mathrm{ml}$.) was added and the yellow solution freed from paper by centrifugation. The optical density of the solution was determined at $430 \mathrm{~m} \mu$. against a blank prepared from a non-coloured area of the chromatogram and compared with those of solutions prepared from known amounts of DAP treated in the same way.

\section{RESULTS}

The release of soluble components from vegetative cell walls of Bacillus cereus during sporulation

Vegetative cell walls of Bacillus cereus contained 30-35\% amino sugars (as glucosamine) and 3-4\% DAP. During vegetative growth, small amounts of these substances were present in the culture medium, but during sporulation the amounts increased rapidly. Shaken cultures of $B$. cereus incubated for $10 \cdot 5,17 \cdot 75,18 \cdot 75$ and $22 \mathrm{hr}$. at $37^{\circ}$ were centrifuged and the supernatant fluids filtered through sintered glass (porosity 5/3). Samples of each filtrate were hydrolysed with $6 \mathrm{~N}-\mathrm{HCl}$ and analysed for hexosamine and DAP (Table 1). After growth for $22 \mathrm{hr}$. free spores predominated and the concentration of hexosamine and DAP in the culture filtrate was four times that found in the $10 \mathrm{hr}$. filtrate from vegetative cells. When samples of the culture filtrates were dialysed, it was found that the bulk of these constituents were non-diffusible indicating that they were present in components of relatively high molecular weight. To obtain these components free from other high molecular weight substances present in the culture medium, washed sporulating cells were allowed to partially autolyse in buffer, $\mathrm{pH} 6 \cdot 0$, containing toluene for $20 \mathrm{hr}$. at $37^{\circ}$. After removal of the cells by centrifugation and filtration through sintered glass, protein was precipitated by saturation of the solution with ammonium sulphate. The protein-free filtrate was dialysed exhaustively against distilled water at $2^{\circ}$ and freeze-dried. A white solid was obtained (97 mg. from 
$1 \cdot 74 \mathrm{~g}$. dry wt./sporulating cells) which contained $45 \%$ amino sugars (as glucosamine), $12 \cdot 7 \%$ carbohydrate excluding hexosamine (as glucose) and $\mathbf{4 . 2} \%$ DAP. After acid hydrolysis followed by paper chromatography, DAP, glutamic acid, alanine, glucosamine and a substituted hexosamine (Strange, 1956) were found to predominate with small amounts of other amino acids. The composition of this material was very similar to that of the peptides released from the isolated cell walls of Bacillus cereus by the enzyme present in spores (Strange \& Dark, 1957).

Table 1. DAP and amino sugar contents of acid-hydrolysis culture mediumfiltrates from vegetative and sporulating cells of Bacillus cereus

$\begin{gathered}\text { Incubation } \\ \text { period of } \\ \text { culture } \\ (\mathrm{hr} .)\end{gathered}$
$\mathbf{1 0 \cdot 5}$
$\mathbf{1 7 \cdot 7 5}$
$\mathbf{1 8 \cdot 7 5}$
$\mathbf{2 2 \cdot 0}$

\begin{tabular}{|c|c|c|c|}
\hline \multirow[b]{2}{*}{ State of cells } & \multirow[b]{2}{*}{$\begin{array}{l}\text { Dry wt. } \\
\text { cells/ml. } \\
\text { (mg.) }\end{array}$} & \multicolumn{2}{|c|}{ 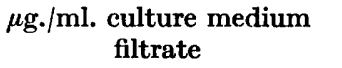 } \\
\hline & & DAP & $\overbrace{\text { Amino sugars }}^{\text {Am glucosamine) }}$ \\
\hline Vegetative forms & $\mathbf{1 \cdot 3 7}$ & $1 \cdot 8$ & $20 \cdot 0$ \\
\hline Intracellular spores & $1 \cdot 40$ & $\mathbf{3 \cdot 0}$ & $24 \cdot 0$ \\
\hline Intracellular spores & $1 \cdot 40$ & $4 \cdot 4$ & $\mathbf{3 2} \cdot 0$ \\
\hline Free spores & $\mathbf{1 \cdot 3 0}$ & $9 \cdot 0$ & $85 \cdot 0$ \\
\hline
\end{tabular}

\section{Activity of the cell-free preparations of lytic enzymes} from sporulating cells

It was established that the soluble products released during partial autolysis of washed sporulating cells of Bacillus cereus included hexosamine-containing peptides and cell-wall lytic enzymes. Preliminary experiments with cell-free preparations indicated that activity was very much greater at $56-58^{\circ}$ than at $37^{\circ}$ and that cobalt ions were stimulatory (see below). The conditions required to give maximum recovery of lytic activity were defined by investigation of the effect of $\mathrm{pH}$ value, time of incubation and the presence of toluene on the autolysis of sporulating cells. A series of suspensions (6 ml.) containing $20 \mathrm{mg}$. dry wt. of sporulating cells/ml. in buffer $\mathrm{pH} \mathrm{5 \cdot 4-7.5}$ with toluene were incubated in parallel with similar suspensions without toluene. Samples (1 ml.) were removed at intervals, freed from cells and tested for lytic activity by turbidity measurements at $\mathrm{pH}$ values of $\mathrm{pH} 4.5$ and $7 \cdot 0$. The results expressed in terms of the time (min.) taken by $0.1 \mathrm{ml}$. autolysate to produce $50 \%$ maximum lysis (Table 2), indicated that optimum conditions for recovery of lytic enzymes were present when a suspension of sporulating cells buffered at pH 5.0-6.0 was incubated for 1-4 hr. at 37 ${ }^{\circ}$. Lytic activity decreased during prolonged incubation but this decrease was lowest at $\mathrm{pH}$ values near 5-0. At acid $\mathrm{pH}$ values toluene had little effect, but above $\mathrm{pH} 6.0$ its presence substantially increased the yield of lytic activity. Examination of films stained for spores (Powell, 1950) and cell walls (Webb, 1954) indicated that after incubation for $1 \mathrm{hr}$. at $37^{\circ}$, complete or substantial spore release occurred under all the conditions used and that vegetative cell walls were dissolved. Of the free spores, a variable number did not stain red in outline which is typical of resting spores but appeared as weakly staining blue rings. It is 
possible that these were immature spores released from the sporangia because of the relatively high concentration of lytic enzymes present in the thick suspensions, before the spore coats had properly developed. They appeared to be as refractile as normal spores when examined in wet preparations. Germinated spores, i.e. forms permeable to stains (Powell, 1950) were most abundant in autolysates incubated in the presence of toluene and vegetative cell structure persisted at $\mathrm{pH}$ values of 6.9 and 7.5 in the absence of toluene. Investigation of autolysis at $\mathrm{pH}$ values of $3 \cdot 0$ and 4.5 were also made. At $\mathrm{pH} \mathrm{3 \cdot 0} \mathrm{little} \mathrm{lysis}$ occurred and only a small amount of lytic enzyme was recovered. Substantial autolysis occurred at $\mathrm{pH} 4.5$ but the activity recovered was less than at pH 5-6.

\section{Table 2. Concentration of lysins in cell-free preparations from partial autolysates of sporulating cells of Bacillus cereus}

Cell-free autolysates $(0 \cdot 1 \mathrm{ml}$. derived from $2 \mathrm{mg}$. dry wt. sporulating cells) tested for lytic activity. Lytic test suspensions (2.5 ml.) contained McIlvaine's buffer, pH 4.5 or 7.0 (1 ml.), B. cereus cell walls $\left(1.5 \mathrm{mg}\right.$.) $\mathrm{Co}^{++}\left(50 \mu \mathrm{g}\right.$.). Incubation at $56^{\circ}$.

Time (min.) to produce $50 \%$ max. lysis by $0.1 \mathrm{ml}$. autolysate

\begin{tabular}{|c|c|c|c|c|c|c|c|}
\hline \multirow{2}{*}{$\begin{array}{l}\text { pH during } \\
\text { autolysis }\end{array}$} & \multirow[b]{2}{*}{ Toluene } & \multicolumn{3}{|c|}{ Lytic tests at pH 4.5} & \multicolumn{3}{|c|}{ Lytic tests at $\mathbf{p H} \mathbf{7} \cdot \mathbf{0}$} \\
\hline & & $1 *$ & 4 & 20 & $1 *$ & 4 & 20 \\
\hline $5 \cdot 4$ & + & $22 \cdot 5$ & $26 \cdot 5$ & 31.5 & $37 \cdot 5$ & $66 \cdot 0$ & 132 \\
\hline $5 \cdot 4$ & - & $17 \cdot 0$ & $26 \cdot 5$ & $39 \cdot 0$ & $22 \cdot 5$ & $57 \cdot 0$ & 375 \\
\hline $6 \cdot 1$ & + & $24 \cdot 0$ & $26 \cdot 5$ & 375 & 34.5 & $79 \cdot 5$ & 375 \\
\hline $6 \cdot 1$ & - & 19.5 & $22 \cdot 5$ & $\dagger$ & $27 \cdot 0$ & $64 \cdot 5$ & 375 \\
\hline 6.9 & + & $25 \cdot 5$ & $84 \cdot 0$ & $\dagger$ & $45 \cdot 0$ & $124 \cdot 5$ & $\dagger$ \\
\hline $6 \cdot 9$ & - & $48 \cdot 0$ & + & $\dagger$ & $t$ & $\dagger^{-}$ & $\dagger$ \\
\hline $7 \cdot 5$ & + & 180 & 375 & $\dagger$ & $63 \cdot 0$ & 375 & $\dagger$ \\
\hline $7 \cdot 5$ & - & 375 & 375 & $\dagger$ & $\dagger$ & $\dagger$ & $\dagger$ \\
\hline
\end{tabular}

The rate of cell-wall lysis in the presence of $0.025-0.1 \mathrm{ml}$. of a typical cellfree autolysate ( $\mathrm{pH} 6 \cdot 0,1 \mathrm{hr}$.) as determined by turbidity measurements is shown in Fig. 1. In the presence of $0.1 \mathrm{ml}$. of the preparation (derived from 2.6 mg. dry wt. of sporulating cells), the optical density of a suspension of cell walls $(1.46 \mathrm{mg} . / 2.5 \mathrm{ml}$.) buffered at $\mathrm{pH} 4 \cdot 6$, was decreased from 0.365 to $0.154\left(58 \%\right.$ decrease) in $1 \mathrm{hr}$. at $56^{\circ}$. Films prepared after incubation and stained for cell walls (Webb, 1954) showed only amorphous debris. The optical density of a control suspension incubated without enzyme remained stationary. The effect of increasing concentrations of $\mathrm{Co}^{++}(0-200 \mu \mathrm{g} . / \mathrm{ml}$.) on lytic activity was determined at $\mathrm{pH}$ values of $5 \cdot 0$ and $7 \cdot 0$. In both cases stimulation occurred which reached a maximum at a concentration of $100 \mu \mathrm{g}$. $\mathrm{Co}^{++} / \mathrm{ml}$. (Fig. 2). When acetate buffer $(0.5 \mathrm{M})$ replaced McIlvaine's buffer at $\mathrm{pH} 5 \cdot 0$, a similar stimulation occurred in the presence of $\mathrm{Co}^{++}$which showed that citric acid was not concerned with this effect.

Some inhibition of activity occurred when the salt concentration of the system was increased. In Mcllvaine's buffer ( $\mathrm{pH} \mathrm{4.5)} \mathrm{containing} \mathrm{KCl}$ in 
concentrations of $0.05,0.1,0.2$ and $0.4 \mathrm{M}$, the time taken to produce $50 \%$ maximum lysis of $1.3 \mathrm{mg}$. cell walls by $0 \cdot 1 \mathrm{ml}$. autolysate was $13 \cdot 5,16 \cdot 5,20$ and $24 \mathrm{~min}$. respectively, compared with $13.0 \mathrm{~min}$. in the absence of $\mathrm{KCl}$. The effect of the added salt on the $\mathrm{pH}$ value of the system was not sufficient to account for the inhibition. Addition of $\mathrm{NaCl}$ or increasing the concentration of the buffer salts also reduced activity. Enzymic activity was completely destroyed by heating preparations at $100^{\circ}$ for $15 \mathrm{~min}$.

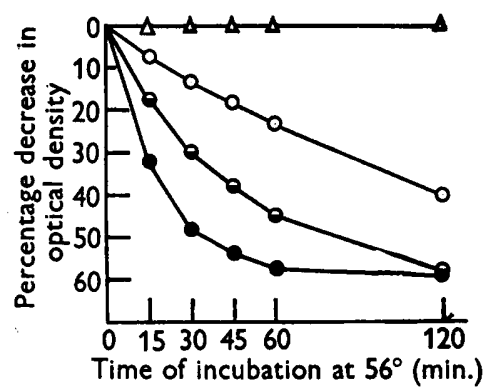

Fig. 1

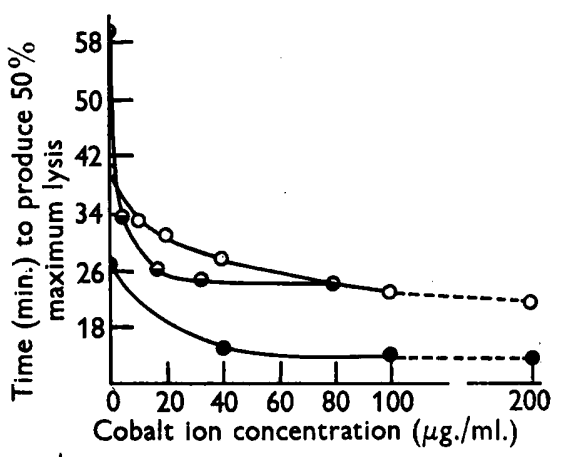

Fig. 2

Fig. 1. The rate of lysis at $56^{\circ}$ of Bacillus cereus cell walls in the presence of various amounts of cell-free autolysate from $B$. cereus sporulating cells: the decrease in turbidity of a cell-wall suspension (1.46 mg. $/ 2.5 \mathrm{ml}$.) buffered at $\mathrm{pH} 4.6$ and incubated with $0.025 \mathrm{ml}$. (O), $0.5 \mathrm{ml}$. ( $\odot), 0.1 \mathrm{ml}$. (O) of the preparation; cell-wall control, $\triangle$.

Fig. 2. Effect of increasing amounts of cobalt ions $(0-200 \mu \mathrm{g} . / \mathrm{ml}$.) on the activity of lytic enzymes from Bacillus cereus sporulating cells: results expressed in terms of the time taken to produce $50 \%$ maximum lysis of cell walls $(1.46 \mathrm{mg} . / 2.5 \mathrm{ml}$.) by a cell-free autolysate (0.1 ml.) in McIlvaine's buffer, pH 5.1 (O), in acetate buffer, pH $5.0(0)$, in McIlvaine's buffer, $\mathrm{pH} \mathrm{7.0}(\Theta)$. Incubation at $56^{\circ}$.

\section{Effect of $\mathrm{pH}$ value on the activity of lytic enzymes from sporulating cells}

The effect of $\mathrm{pH}$ value on lytic activity was determined turbidimetrically and also by estimation of the combined hesoxamine released from the cell-wall substrate. The enzyme preparations contained combined hexosamine and this interfered with subsequent analyses; active material was freed from it by precipitation with $\left(\mathrm{NH}_{4}\right)_{2} \mathrm{SO}_{4}\left(1 \cdot 0\right.$ saturation) at $0^{\circ}$. The precipitate was separated by filtration through sintered glass (porosity $5 / 3$ ) and dissolved in $0.01 \mathrm{M}-\mathrm{NaHCO}_{3}$. When this solution was diluted to the same volume, it was as active as the original preparation but contained an insignificant amount of hexosamine. A series of suspensions $(2.5 \mathrm{ml}$.) buffered in the $\mathrm{pH}$ range $3 \cdot 0-9 \cdot 6$, containing substrate $(3.65 \mathrm{mg}$.), enzyme $(0.05 \mathrm{ml}$. from $1.3 \mathrm{mg}$. sporulating cells) and $\mathrm{Co}^{++}(50 \mu \mathrm{g}$. $)$ were prepared and optical density readings taken. After incubation at $56^{\circ}$ for $2 \mathrm{hr}$. in parallel with controls, further optical density readings were taken, $\mathrm{pH}$ determinations were made and the suspensions were centrifuged. A measured volume $(0.2 \mathrm{ml}$.) of each supernatant fluid was dried at $100^{\circ}$, hydrolysed with $6 \mathrm{~N}-\mathrm{HCl}$ for $2 \mathrm{hr}$. at $100^{\circ}$ and analysed for hexosamine. Decrease in turbidity and release of hexosamine 
followed a similar course and were greatest at $\mathrm{pH}$ values near 4.5 and 8.0 (Fig. 3). It thus appeared that two distinct lytic systems were released from sporulating cells and attempts were made to separate them.

\section{Partial separation and properties of two lytic systems from sporulating cells}

Attempts to separate the two lytic systems by fractionational precipitation with $\left(\mathrm{NH}_{4}\right)_{2} \mathrm{SO}_{4}$ at $0^{\circ}$ were not very successful. A separation based on the relative solubilities of the enzymes at $\mathrm{pH} \mathrm{3.0}$ was more satisfactory and was

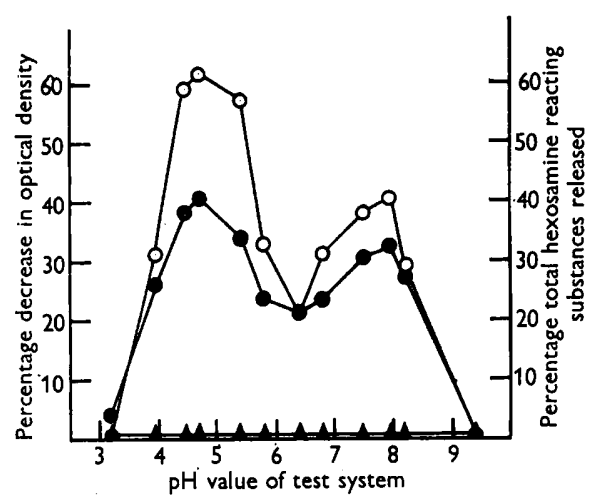

Fig. 3

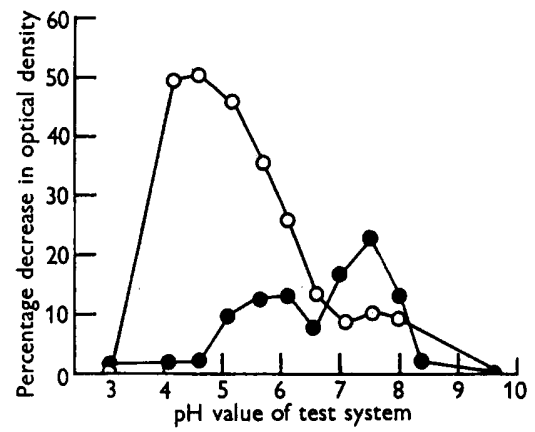

Fig. 4

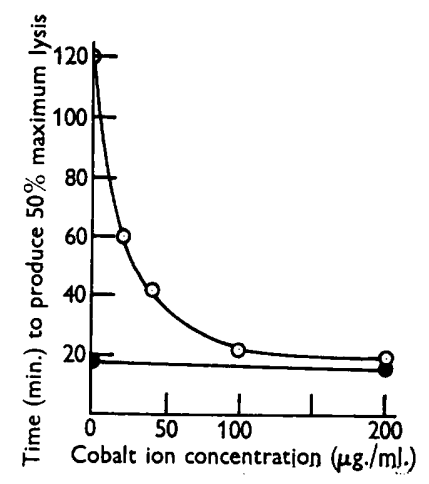

Fig. 5

Fig. 3. Effect of pH on the activity of lytic enzymes from Bacillus cereus sporulating cells in terms of the percentage total combined hexosamine released $(O)$ and percentage decrease in turbidity (O) during incubation for $2 \mathrm{hr}$. at $56^{\circ}$ with cell walls $(3.65 \mathrm{mg}$./ $2.5 \mathrm{ml}$.), cell wall control $(\Delta)$.

Fig. 4. Effect of $\mathrm{pH}$ value on the activity of two lytic enzymes separated from a $1 \mathrm{hr}$. autolysate ( $\mathrm{pH} 6.0$ ) of Bacillus cereus sporulating cells : percentage reduction in turbidity of cell-wall suspensions $(1.4 \mathrm{mg}$. $/ 2.5 \mathrm{ml}$.) with $0.1 \mathrm{ml}$. (from $2.5 \mathrm{mg}$. cells) of enzyme $\mathrm{V}$ in $1 \mathrm{hr}$. at $56^{\circ}(0)$; with $0.1 \mathrm{ml}$. (from $5 \mathrm{mg}$. cells) of enzyme $S$ in $2 \mathrm{hr}$. at $56^{\circ}(0)$.

Fig. 5. Effect of increasing amounts of cobalt ions $(0-200 \mu \mathrm{g}$. $/ \mathrm{ml}$.) on the activity of two lytic enzymes from Bacillus cereus sporulating cells: time taken to produce $50 \%$ maximum lysis of cell walls $(1.5 \mathrm{mg} . / 2.5 \mathrm{ml}$.) by $0.1 \mathrm{ml}$. (from $2.5 \mathrm{mg}$. cells) of enzyme $\mathrm{V}$ at pH 4.5 (O); by $0.1 \mathrm{ml}$. (from 5.0 mg. cells) of enzyme $S$ at pH 6.2 (O). Incubation at $56^{\circ}$. 
achieved as follows: cooled cell-free autolysate ( 1 vol.) was added to cold

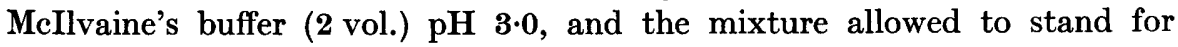
$30 \mathrm{~min}$. at $0^{\circ}$. The precipitate which formed was separated by centrifugation and dissolved in $0.01 \mathrm{M}-\mathrm{NaHCO}_{3}(0.5 \mathrm{vol}$.). This fraction was reprecipitated from the solution by the addition of an equal volume of buffer ( $\mathrm{pH} \mathrm{3.0)}$, and redissolved in $0.01 \mathrm{M}-\mathrm{NaHCO}_{3}(0.5$ vol.). The supernatant fluid from the first precipitate at $\mathrm{pH} 3.0$ was saturated with solid $\left(\mathrm{NH}_{4}\right)_{2} \mathrm{SO}_{4}$ and allowed to stand for $1 \mathrm{hr}$. at $0^{\circ}$. The precipitate which formed was separated by filtration through sintered glass, washed with 0.9 saturated $\left(\mathrm{NH}_{4}\right)_{2} \mathrm{SO}_{4}$ solution and dissolved in $0.01 \mathrm{M}-\mathrm{NaHCO}_{3}(0.5 \mathrm{vol}$.). The effect of $\mathrm{pH}$ value on the activity of these two fractions, i.e. the $\mathrm{pH} \mathrm{3.0}$ insoluble material and the $\left(\mathrm{NH}_{4}\right)_{2} \mathrm{SO}_{4}$ precipitated $\mathrm{pH} \mathrm{3.0}$ soluble material, was determined turbidimetrically. It was found that maximum lysis occurred at $\mathrm{pH}$ values near 8.0 and 4.5 respectively (Fig. 4). The two enzymes are subsequently referred to as 'enzyme S' (pH 3.0 insoluble) and 'enzyme $\mathrm{V}$ ' ( $\mathrm{pH} 3.0$ soluble). When the separation procedure was applied to a number of cell-free autolysates it was found that the relative amounts of the two enzymes varied considerably, depending on the time of incubation and $\mathrm{pH}$ value during autolysis. Another factor which could not be assessed but which probably affected the amounts of lytic enzyme recovered was the precise state of the sporulating cells before autolysis, e.g. the proportion of mature to immature intracellular spores. Enzyme V appeared to

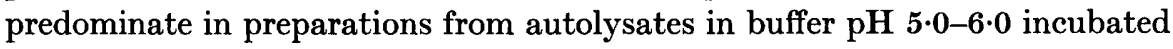
for 1-2 hr. and usually only small amounts of enzyme $S$ were separated. When the suspensions of sporulating cells were incubated for longer periods, the ratio of enzyme $S$ to enzyme $V$ was greater. The two enzymes could also be distinguished by the effect of $\mathrm{Co}^{++}$on their activities. Enzyme $\mathrm{S}$ was progressively more active in the presence of increasing amounts of $\mathrm{Co}^{++}(0-200 \mu \mathrm{g} . / \mathrm{ml}$. $)$, whereas the activity of enzyme $V$ was unaffected (Fig. 5).

\section{Effect of lytic enzymes from sporulating cells on intact vegetative cells}

Cell-free autolysates from sporulating cells attacked suspensions of washed vegetative cells of Bacillus cereus. The decrease in turbidity during incubation at $58^{\circ}$, however, was small: values of $c .16 \%$ decrease were obtained after $1 \mathrm{hr}$. and no further decrease occurred when incubation was continued for several hours. It appeared likely that at $58^{\circ}$ the vegetative cell contents were coagulated and that the decrease in turbidity represented only the dissolution of cell walls. Examination of stained films of the suspensions after incubation with enzyme showed that the walls were dissolved, leaving the cell contents as Gram-negative fragments. A similar result was obtained when cell suspensions were heated at $100^{\circ}$ for $15 \mathrm{~min}$. before incubation at $56^{\circ}$ with lytic enzyme. At $37^{\circ}$ in the presence of thiomersalate (1/5000) the lytic enzymes had no visible effect for several hours, but after $16 \mathrm{hr}$. a $60 \%$ decrease in turbidity occurred, whereas the turbidity of a control suspension incubated for the same period without enzyme increased by $10 \%$. Stained films of the suspensions incubated with lysins at $37^{\circ}$ showed no evidence of residual cell 
structures. The lytic enzymes had no obvious effect on suspensions of viable or heat-killed vegetative cells of $B$. megaterium at either 37 or $56^{\circ}$.

\section{Investigation of non-sporulating cells and culture medium filtrate for the presence of lytic enzymes}

Washed Bacillus cereus harvested from potato-extract medium after growth for $9.5 \mathrm{hr}$. at $37^{\circ}$ appeared as Gram-positive rods in stained films and showed no evidence of sporulation. After incubation of a suspension in buffer $(\mathrm{pH} \mathrm{6.0})$ containing toluene for $4 \mathrm{hr}$. at $37^{\circ}$ the organisms showed no evidence of lysis but were now Gram-negative. Examination of films stained by Webb's (1954) method showed that the cell walls had not been dissolved. A cell-free preparation from the incubated suspension had no detectable lytic activity against $B$. cereus cell walls. The culture medium filtrate from sporulating cells of $B$. cereus after growth for $18 \mathrm{hr}$. was saturated with ammonium sulphate and the resulting precipitate was tested for lytic activity. An insignificant amount of lytic enzyme was present.

\section{Comparison of the lysins from sporulating cells with the lysin present in spores}

It was previously found that a cell-wall lytic enzyme present in extracts of disintegrated resting spores of Bacillus cereus and other Bacillus spp. showed optimum activity at $\mathrm{pH} 7-8$ in the presence of cobalt ions at $58^{\circ}$ (Strange \& Dark, 1957). Re-examination of the effects of $\mathrm{pH}$ value and increasing amounts of $\mathrm{Co}^{++}$on the activity of this lysin indicated that its properties were very similar to those of enzyme $S$ (Figs. 6, 7). Both the spore enzyme and enzyme $S$ were insoluble at $\mathrm{pH} 3 \cdot 0$ and this property had been used for the

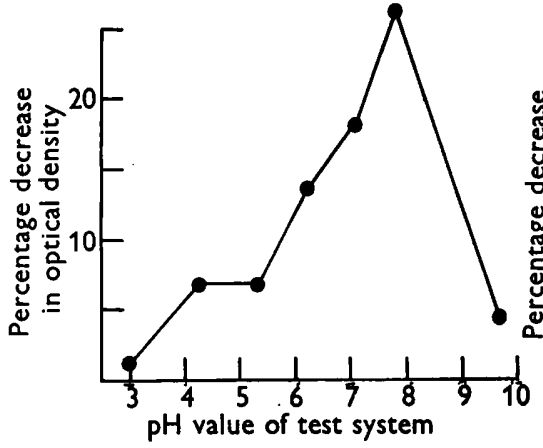

Fig. 6

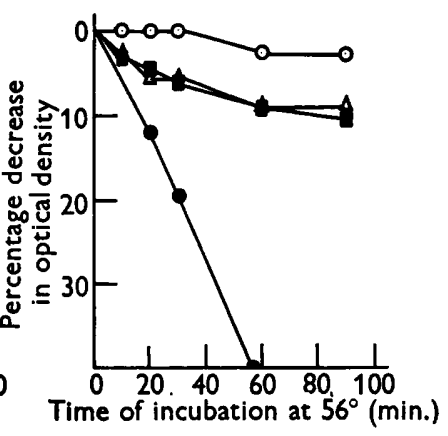

Fig. 7

Fig. 6. Effect of $\mathrm{pH}$ value on the activity of lytic enzyme in extracts of disintegrated resting spores of Bacillus cereus: percentage decrease in turbidity of cell-wall suspensions (1.3 mg. $/ 2.5 \mathrm{ml}$.) containing buffer (1 ml.) cobalt ions $(20 \mu \mathrm{g}$.) and enzyme from $5 \mathrm{mg}$. spores, after incubation for $2 \mathrm{hr}$, at $56^{\circ}$.

Fig. 7. Effect of cobalt on the activity of lytic enzyme from resting spores of Bacillus cereus : percentage decrease in turbidity of cell-wall suspensions $(1.3 \mathrm{mg} / 2.5 \mathrm{ml}$.) containing enzyme from $2.5 \mathrm{mg}$. spores at $\mathrm{pH} 4.9$ without cobalt $(O)$ and with $20 \mu \mathrm{g} . \mathrm{Co}^{++} / \mathrm{ml} .(\Delta)$; at $\mathrm{pH} 7 \cdot 1$ without cobalt (E) and with $20 \mu \mathrm{g} . \mathrm{Co}^{++} / \mathrm{ml}$. (O). 
separation of spore enzyme from spore peptide. The possibility that some enzyme $\mathrm{V}$ was also present in resting spores was checked by testing the activity of material precipitated from spore extracts with $\left(\mathrm{NH}_{4}\right)_{2} \mathrm{SO}_{4}(1.0$ saturation). The results showed that resting spores contained little or no enzyme $V$.

Evidence that peptide is released from spore coats by enzymic activity during mechanical disintegration of spores

In previous reports (Powell \& Strange, 1956; Strange \& Dark, 1957) it was suggested that the function of enzyme $S$ in spores is to release peptide from the spore coat during germination and that the presence of soluble peptide in aqueous extracts of disintegrated spores is due to the attack of enzyme $\mathbf{S}$ on the spore coat during mechanical disintegration. However, Powell \& Strange (1957) were unable to demonstrate a cell-wall lytic enzyme similar to enzyme $\mathbf{S}$ in spores of Bacillus sphaericus. Spore extracts did not attack vegetative cell walls of this organism or those of $B$. cereus. Spore peptide was found in extracts from $B$. sphaericus spores, while the coats contained relatively small amounts of peptide as indicated by their low content of DAP and amino

Table 3. Hexosamine content of acid-hydrolysed spore coats of Bacillus cereus and B. sphaericus NCTC 9602 isolated from spores disintegrated at different $\mathrm{pH}$ values

$\begin{array}{lcc}\text { Source of coats } & \begin{array}{c}\text { pH during } \\ \text { disintegration }\end{array} & \begin{array}{c}\text { Hexosamine } \\ \text { (g./100g. spore coats) }\end{array} \\ \text { Bacillus cereus spores } & \mathbf{5 \cdot 0} & \mathbf{3 \cdot 0} \\ \text { B. cereus spores } & \mathbf{7 \cdot 4} \text { (water) } & \mathbf{2 \cdot 3} \\ \text { B. cereus spores } & \mathbf{9 \cdot 6} & \mathbf{6 \cdot 2} \\ \text { B. sphaericus (NCTC 9602) spores } & \mathbf{7 \cdot 4} \text { (water) } & \mathbf{2 \cdot 3} \\ \text { B. sphaericus (NCTC 9602) spores } & \mathbf{9 \cdot 6} & \mathbf{6 \cdot 5}\end{array}$

sugars. It seemed possible, though unlikely, that in $B$. sphaericus the spore peptide was not attached to the spore coat and appeared in spore extracts independently of a lytic system. This possibility can now be excluded on the following grounds: enzyme $\mathrm{S}$ in spores of $\boldsymbol{B}$. cereus was inactive at $\mathrm{pH} 9 \cdot 6$ (see above). If in fact the detachment of the peptide from the spore coat during disintegration depends on the activity of enzyme $\mathrm{S}$, disintegration at $\mathrm{pH} \mathbf{9 \cdot 6}$ should yield spore coat preparations of relatively high DAP and hexosamine content. This was found to be the case. Thus spore suspensions of $B$. cereus and $B$. sphaericus (NCTC 9602) in distilled water (c. $10 \mathrm{mg}$. dry wt./ml.) were disintegrated in a Mickle (1948) tissue disintegrator and the spore coat fractions isolated by centrifugation. After washing several times in saline $(0.9 \% \mathrm{NaCl}$, $\mathrm{w} / \mathrm{v}$ ) and distilled water, the coats were freeze-dried. Similar preparations were made from spores suspended in $0.5 \mathrm{M}-\mathrm{Na}_{2} \mathrm{CO}_{3} / \mathrm{NaHCO}_{3}(\mathrm{pH} \mathrm{9.6})$ and also, in the case of $B$. cereus, from a suspension in $0.5 \mathrm{M}$-sodium acetate/acetic acid (pH 5.0). During the washing of the coats from buffered homogenates, possible enzymic activity was minimized by using dilute solutions (1/10) of the appropriate buffers and distilled water as the final wash. Analyses (Table 3) 
of the acid-hydrolysed coats showed that considerably more hexosamine was present in those from spores disintegrated at $\mathrm{pH} 9 \cdot 6$ than at $\mathrm{pH} 7 \cdot \mathbf{4}$ or $\mathrm{pH} \mathbf{5 \cdot 0}$. When coats from the $\mathrm{pH} 9 \cdot 6$ homogenates were suspended in buffer $(\mathrm{pH} 7 \cdot \mathbf{1})$ containing $\mathrm{Co}^{++}(10 \mu \mathrm{g}$. $/ \mathrm{ml}$. $)$ and incubated for $2 \mathrm{hr}$. at $56^{\circ}$ a considerable release of hexosamine-containing components occurred (Table 4). However, when the coats were heated at $100^{\circ}$ for $15 \mathrm{~min}$. before incubation in buffer, a much smaller release of material occurred. Addition of the homologous sporeextract or lysin $\mathrm{S}$ to heat-inactivated spore coats caused release of hexosamine-containing material in similar amounts to those released spontaneously from non-heated coats (Table 4).

\section{Table 4. Release of combined hexosamine from spore coats of Bacillus cereus and B. sphaericus NCTC 9602}

Suspensions $(0.5 \mathrm{ml}$.) contained McIlvaine's buffer (pH 7.1), 0.2 ml., cobalt, $5 \mu \mathrm{g}$. and spore coats. Incubation, $2 \mathrm{hr}$. at $58^{\circ}$. Hexosamine was determined in the supernatant fluids after hydrolysis with $6 \mathrm{~N}-\mathrm{HCl}$ for $2 \mathrm{hr}$. at $100^{\circ}$. The Bacillus cereus spore extract was freed from hexosamine, whereas that from B. sphaericus was not: this is allowed for in the results.

\begin{tabular}{|c|c|c|c|c|c|}
\hline $\begin{array}{l}\text { Source of } \\
\text { spore coats }\end{array}$ & $\begin{array}{l}\text { Wt. } \\
\text { (mg.) }\end{array}$ & Source of extract & $\begin{array}{c}\text { Substrate } \\
\text { hexosamine } \\
(\mu \mathrm{g} .)\end{array}$ & $\begin{array}{l}\text { Hexos- } \\
\text { amine } \\
\text { released } \\
(\mu \mathrm{g} .)\end{array}$ & $\begin{array}{l}\text { Percentage } \\
\text { substrate } \\
\text { hexosamine } \\
\text { released }\end{array}$ \\
\hline Bacillus cereus & 5 & - & 310 & 108 & 35 \\
\hline B. cereus & $5(\mathbf{H})$ & - & 310 & 12 & 4 \\
\hline B. cereus & $5(\mathbf{H})$ & $6 \mathrm{mg}$. B. cereus spores & 310 & 79 & 26 \\
\hline B. sphaericus & 5 & - & 325 & 225 & 69 \\
\hline B. sphaericus & $4.9(\mathrm{H})$ & - & 304 & 62 & 20 \\
\hline B. sphaericus & $4.9(\mathrm{H})$ & $5 \mathrm{mg}$. B. sphaericus spores & 304 & $290-56 *$ & 77 \\
\hline
\end{tabular}

\section{DISCUSSION}

The results of the present work establish that there are two distinct lytic systems present in sporulating cells of Bacillus cereus. Neither of these was detected in non-sporulating vegetative cells and only small amounts were found in concentrates of the filtered culture medium from intact, i.e. nonautolysed sporulating cells. Lysis of the sporangia to allow spore release appears to be due to one or both of these intracellular lytic enzymes. One of these enzymes $(S)$ is probably identical with that found in extracts of disintegrated $B$. cereus resting spores and might have been derived from immature spores which lysed under the experimental conditions used. The mode of attack of both enzyme $\mathbf{S}$ and enzyme $\mathbf{V}$ is readily distinguishable from that of the lytic principle'associated with non-sporulating cells of a strain of $B$.cereus (Norris, 1957) which dissolved the protoplasts of vegetative cells of a number of Bacillus spp., leaving the cell walls. Dr J. R. Norris (private communication) has found that these residual cell walls are dissolved by a preparation of $B$. cereus enzyme $\mathrm{S}$ which we supplied. It is not possible to compare the activity of either enzyme $\mathrm{S}$ or $\mathrm{V}$ with that of the lytic substance from $\boldsymbol{B}$. cereus var. terminalis described by Greenberg \& Halvorson (1955), since these 
authors did not define the lytic substrate. The lytic enzyme demonstrated in autolysates of $B$. subtilis vegetative cells (Nomura \& Hosoda, 1956) resembled enzymes $S$ and $V$ in its mode of action, attacking vegetative cell-wall preparations of this organism; this system appeared in non-sporulating cultures. We have found that buffered suspensions of washed vegetative cells of a laboratory strain of $B$. subtilis showing no evidence of sporulation, autolysed on incubation at $37^{\circ}$ or $56^{\circ}$, whereas suspensions of vegetative cells of $B$. megaterium and $B$. cereus were stable. Suspensions of cell walls isolated from vegetative B. subtilis also lysed spontaneously and this was not completely prevented by heating them at $100^{\circ}$ for 15 min. (Strange \& Dark, 1957).

The action of enzymes $\mathbf{S}$ and $\mathbf{V}$ on heat-killed vegetative cells and cell walls resembles that of lysozyme. Salton (1953) showed that the walls of heat-killed Bacillus megaterium were dissolved by lysozyme but the coagulated cell contents were left unchanged. However, whereas lysozyme was much more active against intact cells of $\boldsymbol{B}$. megaterium and $\boldsymbol{B}$. subtilis than those of $B$. cereus (Salton, 1956), enzymes $S$ and $V$ attacked intact cells of $B$. cereus but not those of $B$. megaterium. Enzyme $S$ from $B$. cereus spores attacked the isolated cell walls from all three organisms (Strange \& Dark, 1957).

The results of previous work with Bacillus sphaericus (Powell \& Strange, 1957) showed that this organism differed biochemically in a number of ways from other members of the group. For example, the peptide component present in vegetative cell walls contained lysine instead of $\alpha, \epsilon$-diaminopimelic acid. B. sphaericus spore peptide did contain $\alpha, \epsilon$-diaminopimelic acid and resembled peptides present in vegetative cell walls and spores of other Bacillus spp. It has now been shown that $B$. sphaericus spores contain a lytic enzyme with similar properties to those of enzyme $S$. The inability of this enzyme to dissolve $B$. sphaericus vegetative cell walls might be due to the different composition of the peptide present.

The interpretation of lysis caused by substances of bacterial origin must take into account the possibility that the agent is a bacteriophage or bacteriocin. The enzymes described in the present work attacked substrates of heat-killed bacteria and their optimum temperature for lytic activity was near $56^{\circ}$; they appear to play a definite part in sporulation and spore germination. These properties are akin to those of an enzyme rather than a bacteriophage or bacteriocin.

We wish to thank Mrs Joan F. Powell for reading and criticizing the manuscript. We are grateful for her interest in this work.

\section{REFERENCES}

Chinard, F. P. (1952). Photometric estimation of proline and ornithine. J. biol. Chem. 199, 91.

Gladstone, G. P. \& Fildes, P. (1940). A simple culture medium for general use without meat extract or peptone. Brit. J. exp. Path. 21, 161.

Gomori, G. (1946). Buffers in the range of pH 6.5 to 9.6. Proc. Soc. exp. Biol., N.Y. 62, 33. 
Greenberg, R. A. \& Halvorson, H. D. (1955). Studies on an autolytic substance produced by an aerobic spore forming bacterium. J. Bact. 69, 45.

Mickle, H. (1948). Tissue disintegrator. J. R. micr. Soc. 68, 10.

Nomura, M. \& Hosoda, J. (1956). Nature of the primary action of the autolysin of Bacillus subtilis. J. Bact. 72, 573.

Norris, J. R. (1957). A bacteriolytic principle associated with cultures of Bacillus cereus. J. gen. Microbiol. 16, 1.

Powell, J. F. (1950). Factors affecting the germination of thick suspensions of Bacillus subtilis spores in L-alanine solution. J. gen. Microbiol. 4, 330.

Powell, J. F. \& Strange, R. E. (1956). Biochemical changes occurring during sporulation in Bacillus species. Biochem. J. 63, 661.

Powell, J. F. \& Strange, R. E. (1957). $\alpha, \epsilon$-Diaminopimelic acid metabolism and sporulation in Bacillus species. Biochem. J. 65, 700.

Rhuland, L. E., Work, E., Denham, R. F. \& Hoare, D. S. (1955). The behaviour of the isomers of $\alpha, \epsilon$-diaminopimelic acid on paper chromatograms. J. Amer. chem. Soc. 77, 4844.

Robinow, C. F. (1951). Observations on the structure of Bacillus spores. J. gen. Microbiol. 5, 439.

Salton, M. R. J. (1953). Cell structure and the enzymic lysis of bacteria. J. gen. Microbiol. 9, 512.

SALton, M. R. J. (1956). Bacterial cell walls. In Bacterial Anatomy. Symp. Soc. gen. Microbiol. 6, 81.

Strange, R. E. (1956). The structure of an amino sugar present in certain spores and bacterial cell walls. Biochem. $J .64,23 P$.

Strange, R. E. \& Dark, F. A. (1956). The composition of the spore coats of Bacillus megaterium, B. subtilis and B. cereus. Biochem. J. 62, 459.

Strange, R. E. \& Dark, F. A. (1957). A cell-wall lytic enzyme associated with spores of Bacillus species. J. gen. Microbiol. 16, 236.

Strange, R. E. \& Powell, J. F. (1954). Hexosamine-containing peptides in spores of Bacillus subtilis, B. megaterium and B. cereus. Biochem. J. 58, 80.

WEBB, R. B. (1954). A useful bacterial cell wall stain. J. Bact. 67, 252.

Work, E. (1957). Reaction of $\alpha, \epsilon$-diaminopimelic acid and its homologues with ninhydrin in acid solution. Biochem. J. (in the Press). 